\title{
Antistreptolysin levels in normal infants and young children
}

\author{
C. W. POTTER AND J. LORBER \\ From the Department of Pathology, Children's Hospital, Sheffield, and \\ Department of Child Health, University of Sheffield
}

SYNOPSIS A modified method of estimating the antistreptolysin O titre (A.S.O.) is described. The A.S.O. of 279 sera from normal children under 5 years of age is recorded, together with that of 40 children over 5 years of age. The results show a range much lower than that found in adults and older children and are discussed with respect to estimations made in children with proven infections. The significance of these findings is discussed.

Of the serological tests used in the diagnosis of streptococcal infections, the estimation of the A.S.O. has emerged as the most consistent and reliable. First introduced by Todd (1932a and b) and modified by other workers (Hodge and Swift, 1933; Rantz and Randall, 1945) the test is a routine procedure to aid in the diagnosis of rheumatic fever, nephritis, and other post-streptococcal conditions. In adults the upper limit of normal is taken by Rantz (1955) and Lawy (1960) as 200 Todd units/ml., while Wood and McCarty (1954) and Hollinger (1953) consider that 250 units $/ \mathrm{ml}$. should be the upper limit. Studying a series of patients suffering from rheumatic fever, Wood and McCarty (1954) demonstrated that 80 to $90 \%$ of patients showed significantly raised A.S.O. levels. Stollerman, Lewis, Schultz, and Taranta (1956), in a series of 20similar cases, claimed that 19 showed titres which are considered significant. McCarty (1952a) asserted that significant levels are found in 70 to $80 \%$ of all cases of proven streptococcal infection. In adults and older children, the value of the test is considerable.

In children under 5 years of age, the test is considered to be of limited value. McCarty (1952b) included in a series of rheumatic fever cases two children under 5 years of age. Neither showed at any time an A.S.O. of more than 25 units $/ \mathrm{ml}$. Rantz, Maroney, and Di Caprio (1951) investigated 52 cases of proven streptococcal infection in young children and divided them into three categories, depending on the antibody response and the rate of fall in titre. In Rantz's first group, in which the average age was $14 \cdot 3$ months, a maximum titre of 12 units $/ \mathrm{ml}$. was

Received for publication 23 January 1961. found in six of 13 children, the others showing no response. In the second group, in which the average age was 36.7 months, six of 18 showed peak titres of 50 units $/ \mathrm{ml}$. while the mean peak titre was 235 units/ $\mathrm{ml}$. The levels, however, fell to 12 units $/ \mathrm{ml}$. in a mean time of 40.5 days for the six showing a small response and a maximum of 130 days for the other 12. In the third group, in which the mean age was 57.9 months, the titres found and the rate of fall was comparable to the pattern found in adults and older children. Of 18 normal children between the ages of $1 \frac{1}{2}$ and 3 years, Rantz found levels of less than 12 units in 17.

During the first weeks of life high levels were found. Lippard and Wheeler (1936) showed that this was due to passively acquired maternal antibody. This was also noted by Wilson, Wheeler, and Leask (1934). It appears that the normal levels and titres found in cases of proven streptococcal infection are of a very different order in children under 5 years of age as compared with older children and adults. Estimations carried out on children of this age group cannot be interpreted in terms of adult normal and abnormal values.

The present investigation was carried out in order to find what A.S.O. levels could be expected in normal children under 5 years of age, and to serve as a base line for the interpretation of results found in clinical cases of infection.

\section{MATERIALS}

From sera submitted to the laboratory in excess of the laboratory's requirements for routine tests in a variety of conditions, 319 were collected and stored at $-20^{\circ} \mathrm{C}$. The sera were in the main from infants examined before 
adoption and clean surgical cases admitted for treatment (burns, cleft palate, hare lip, and accident). Sera from children with renal disorders, leukaemia, or with a history of acute or post-respiratory tract infections or blood transfusions were not included.

The method of estimation of A.S.O. levels has been modified by one of us. Details are given in the Appendix (C.W.P.).

\section{RESULTS}

Table I shows the number of sera giving the same A.S.O. for the corresponding age group. No levels of 200 units $/ \mathrm{ml}$. or more were found in 319 sera tested, and 152 showed no detectable A.S.O. at a dilution of $1 / 8$ (Table II shows the summarized results). In infants under 2 months of age the A.S.O.s are of a higher order than in any other age group under 5 years of age. Only 11 out of $85(13 \%)$ show no detectable level and $51 / 85(60 \%)$ showed levels between 32 and 192 units $/ \mathrm{ml}$. In contrast, no detectable levels were found in $84 \%$ and $86 \%$ respectively in infants aged 2 to 12 and 13 to 24 months. Only three of 126 sera from children between 2 months and 2 years of age showed titres of 32 units $/ \mathrm{ml}$. or more. Between the ages of 2 years and 5 years, however, only 25 of $68(36.8 \%)$ gave undetectable titres and $31(45.6 \%)$ gave titres of 32 units or more. These levels represent the levels that exist in a cross section of presumably normal children of these age groups and are much lower than in older children or adults. Forty sera from children 5 years to 7 years of age are included for comparison. Detectable levels may be due to past subclinical or undiagnosed infections by $\beta$-haemolytic streptococci.

\section{DISCUSSION}

It is generally agreed that in children under 2 months of age the antistreptolysin ' $\mathrm{O}$ ' is passively acquired from the mother. The levels fall quickly and disappear at about 2 months of age, as can be seen from Table I. In interpreting results obtained in these young babies this factor must be taken into account, as this fall could mask any response which might occur as a result of streptococcal infection. In fact, it is not yet known if any response does occur in the presence of maternal antibody.

Between the ages of 2 months and 2 years detectable antibody was found in only 19 of 126 sera. Further studies of this age group are necessary to find whether these titres are significant as evidence of past infection by comparing them with titres from children with proven $\beta$ haemolytic streptococcal infections. Rantz et al. (1951) found that of 13 children (average age 14.3 months) with proven infections, six gave titres of 12 units $/ \mathrm{ml}$., while of our normal series only 11 out of 126 have titres of

\section{TABLE I}

NUMBER OF SERUM SPECIMENS GIVING SIMILAR A.S.O. FOR THE VARIOUS AGE GROUPS

\begin{tabular}{|c|c|c|c|c|c|c|c|c|c|c|c|c|c|c|c|c|c|c|c|}
\hline \multirow{2}{*}{$\begin{array}{l}\text { A.S.O. } \\
\text { (Todd } \\
\text { units } / \mathrm{ml} . \text { ) }\end{array}$} & \multicolumn{19}{|c|}{ Age (Months) } \\
\hline & $0-2$ & $3-4$ & $5-6$ & $7-8$ & $9-10$ & $10-12$ & $13-14$ & $15-16$ & $17-18$ & $19-20$ & $21-22$ & $23-24$ & $25-30$ & $31-36$ & $37-42$ & $43-48$ & $49-54$ & $55-60$ & $>60$ \\
\hline $192->$ & - & - & - & - & - & - & - & - & - & - & - & - & - & - & - & 1 & 1 & - & 1 \\
\hline $128-191$ & 2 & - & - & - & - & - & - & - & - & - & - & - & - & - & - & - & - & 1 & 7 \\
\hline $96-127$ & 7 & - & - & - & - & - & - & - & - & - & - & - & 1 & - & - & 1 & 3 & 1 & 5 \\
\hline 64- 95 & 12 & - & - & - & - & - & - & - & - & - & - & 1 & 1 & 1 & 2 & 3 & 1 & $i$ & 9 \\
\hline 48- 63 & 17 & - & - & - & 一 & 一 & - & - & - & - & - & - & - & 2 & 2 & 1 & - & 2 & 1 \\
\hline $32-47$ & 13 & 1 & - & 1 & - & - & - & - & - & - & - & - & 1 & 1 & 1 & $i$ & 1 & 1 & 3 \\
\hline 24- 31 & 10 & - & - & - & - & - & - & - & - & - & - & 1 & 3 & - & - & - & - & 1 & 1 \\
\hline 16- 23 & 10 & - & - & 2 & 1 & 1 & 1 & - & - & - & - & - & 2 & - & 1 & - & - & 1 & 4 \\
\hline $12-15$ & 1 & 1 & - & - & - & - & - & - & - & - & - & 1 & - & - & 1 & - & - & - & - \\
\hline $8-11$ & 2 & 1 & 2 & 2 & - & - & 1 & - & 2 & - & - & - & 1 & - & 1 & - & - & 1 & - \\
\hline 8 & 11 & 13 & 15 & 12 & 13 & 11 & 10 & 9 & 6 & 3 & 3 & 12 & 10 & 7 & 3 & 2 & 2 & 1 & 9 \\
\hline
\end{tabular}

TABLE II

SUMMARIZED RESULTS OF A.S.O. LEVELS FOR VARYING AGE GROUPS WITH CORRESPONDING PERCENTAGES OF TOTAL NUMBERS

\begin{tabular}{|c|c|c|c|c|c|}
\hline \multirow[t]{2}{*}{ A.S.O. (Todd units $/ \mathrm{ml})}$. & \multicolumn{4}{|c|}{ Age (Months) } & \multirow[t]{2}{*}{ Total } \\
\hline & $0-2$ & $3-24$ & $25-60$ & $>60$ & \\
\hline $\begin{array}{r}>32 \\
8-31 \\
<8\end{array}$ & $\begin{array}{l}51(60 \%) \\
23(27 \%) \\
11(13 \%)\end{array}$ & $\begin{array}{c}3(2 \cdot 3 \%) \\
16(12 \cdot 7 \%) \\
107(85 \%)\end{array}$ & $\begin{array}{l}31(45 \cdot 6 \%) \\
12(17 \cdot 6 \%) \\
25(36.8 \%)\end{array}$ & $\begin{array}{l}26(65 \%) \\
5(12 \cdot 5 \%) \\
9(22 \cdot 5 \%)\end{array}$ & $\begin{array}{r}111 \\
56 \\
152\end{array}$ \\
\hline Total & 85 & 126 & 68 & 40 & 319 \\
\hline
\end{tabular}


12 units or more. The analysis of Rantz's cases was based on the type of response rather than on age.

Between the ages of 2 years and 5 years of age (Table I) the number of sera showing no detectable A.S.O. decreased and the number of sera showing measurable levels tended to increase with age. This is as would be expected after repeated contact with $\beta$ haemolytic streptococci. Rantz et al. (1951) found that in cases of proven streptococcal infecton two groups of children with average ages of 36.5 months and 57.9 months gave average peak titres of 235 units $/ \mathrm{ml}$. and 495 units $/ \mathrm{ml}$. respectively. In our normal children, however, only nine of 68 sera showed titres of over 100 units $/ \mathrm{ml}$.

Analysis according to age is not the only method of approach to this problem, for it has been suggested that the response to infection, either clinical or subclinical, is probably dependant on whether response has been initiated by previous contact with the antigenic stimulus and only a detailed history would give the position of an individual patient with respect to past infection. Rantz et al. (1951) and Rantz (1955) have shown that initiation by proven infection allows for a more active response when a child is reinfected.

The significance, therefore, of A.S.O. levels in children in the younger age groups should be considered with respect to normal levels in a corresponding age group and not against normal levels established in older persons. In this respect the work of Holborow and Isdale (1956) on the 'sensitization' concept of Powers and Boisvert (1944) and Rantz et al. (1951) should be reconsidered.

\section{APPENDIX}

MATERIALS The following were used:-

1 Haemolysin 0 is the standard haemolysin 0 (Difco Laboratories).

2 Isotonic buffer solution and red cell suspension (Rantz and Randall, 1945).

3 Perspex haemagglutination trays (Prescott Ltd.).

4 The pipette is the interchangeable, automatic Everett pipette (Turner \& Sons Ltd.) of $\mathbf{0 . 2} \mathrm{ml}$. delivery volume.

METHOD By placing two or more trays side by side the number of dilutions tested can be made as large as required. For the purposes of this investigation 12 dilutions were tested. A single pipette was used throughout.

1 To a horizontal row of wells, 1 to 12 , one volume of buffer was added to all the wells except well 1 .

2 From a serum dilution of $1: 4,1$ vol. was placed in well 1,2 vol. in well 2 , and 1 vol. in well 3 . The pipette was flushed out twice with clean buffer solution, discarding each washing.

3 The contents of well 3 were mixed with the automatic pipette and 1 vol. transferred to well 5 . The pipette was flushed out once with clean buffer solution, discarding the washing, a procedure repeated after every subsequent transfer of volumes unless otherwise stated.

4 The contents of well 5 were mixed with the automatic pipette and 1 vol. transferred to well 7. This process was repeated for all the odd numbered wells in the series, a volume from well 11 being discarded. The pipette was not flushed out after well 11 .

5 The contents of well 2 were mixed, 1 vol. was discarded and 1 vol. transferred to well 4.

6 The contents of well 4 were mixed and one volume transferred to well 6 . This is continued for all the even numbered wells, discarding 1 vol. from well 12 .

7 After the dilution series was completed the pipette was flushed out 10 times, discarding each washing, and 1 vol. of buffer was placed in every well. The resulting series of dilutions was $1: 8,1: 12,1: 16,1: 24,1: 32$, etc. to $1: 384$.

8 The trays were left at $37^{\circ} \mathrm{C}$. for $30 \mathrm{~min}$.

9 One volume of standard haemolysin 0 was added to each well, and the trays further incubated at $37^{\circ} \mathrm{C}$. for $15 \mathrm{~min}$.

10 One volume of the $5 \%$ red cell suspension was added to each well and the trays incubated for $45 \mathrm{~min}$. at $37^{\circ} \mathrm{C}$.

11 The trays were then placed at $+4^{\circ} \mathrm{C}$. overnight and then read against a white background. Titres were given as the highest dilution of sera giving complete neutralization of the haemolysin suspension, i.e., showing no trace of lysis.

If the stock serum dilution of $1: 50$ is taken and the same technique used the dilution series is $1: 100$; $1: 150 ; 1: 200 ; 1: 300$, etc., and this method was used for estimations carried out in routine laboratory investigations.

One hundred and fourteen sera with titres between 12 units $/ \mathrm{ml}$. and 800 units $/ \mathrm{ml}$. were carried out in parallel with the method of Rantz and Randall (1945). The results are comparable and results using our technique are expressed in Todd units $/ \mathrm{ml}$. Once familiar with using an automatic pipette, the technique is both time saving and easier to prepare. Smaller quantities of reagents are required and results are easily interpreted.

\section{REFERENCES}

Hodge, B. E., and Swift, H. F. (1933). J. exp. Med., 58, 277.

Holborow, E. J., and Isdale, I. C. (1956). Lancet, 1, 649.

Hollinger, N. F. (1953). Amer. J. Publ. Hlth, 43, 561

Lawy, H. S. (1960). Ann. rheum. Dis., 19, 42.

Lippard, V. W., and Wheeler, G. W. (1936). Amer. J. Dis. Child., 52, 61.

McCarty, M. (1952a). Bull. N.Y. Acad. Med., 28, 307.

- (1952b). Ann. intern. Med., 37, 1027.

Powers, G. F., and Boisvert, P. L. (1944). J. Pediat., 25, 481

Rantz, L. A. (1955). Med. Clin. N. Amer., 39, 339.

-, and Randall, E. (1945). Proc. Soc. exp. Biol. (N. Y.), 59, 22.

, Maroney, M., and Di Caprio, J. M. (1951). A.M.A. Arch. intern. Med., 87, 360.

Stollerman, G. H., Lewis, A. J., Schultz, I., and Taranta, A. (1956) Amer. J. Med., 20, 163.

Todd, E. W. (1932a). J. exp. Med., 55, 267.

(1932b). Brit. J. exp. Path., 13, 248.

Wilson, M. G., Wheeler, G. W., and Leask, M. M. (1934). Proc. Soc. exp. Biol. (N.Y.), 31, 1001.

Wood, H. F., and McCarty, M. (1954). Amer. J. Med., 17, 768. 